\title{
Cashless Banking and Financial Performance of Bank Rakyat Indonesia
}

\author{
Nyi Ayu Helfasari ${ }^{1}$, Rindu Rika Gamayuni ${ }^{2}$, Usep Syaipudin ${ }^{3}$, \\ \{helfasari@gmail.com ${ }^{1}$, rindu.gamayuni@yahoo.com ${ }^{2}$, usepsyaipudin@gmail.com ${ }^{3}$ \} \\ Lampung University, Jln. Soemantri Brodjonegoro No. 1,Bandar Lampung, 35141, Lampung, \\ Indonesia ${ }^{1,2,3}$
}

\begin{abstract}
This study aims to examine the effect of cashless transactions, on financial performance. The study focused on Bank Rakyat Indonesia using quarterly data for the 2012-2018 period. Whereas the comparative model used data 10 quarters before August 2014 and 10 quarters after August 2014.Data were analyzed using multiple linear regression analysis and a paired sample t-test comparison test. This study shows empirical evidence that the cashless variable, namely debit / ATM cards, credit cards, checks and bilyet transfers, electronic money and mobile banking, only the variables bilyet and bank checks which has no effect on profitability. This study also showed that there were differences between the financial performance variables measured using the return on equity before the return on equity after the Non-Cash National Movement launched by Bank Indonesia on August 14, 2014, whereas for the Loan to Deposit Ratio variable there is no difference.
\end{abstract}

Keywords: Cashless Banking, Financial Performance, ROE, LDR

\section{Introduction}

The purpose of a cashless bank transaction is to replace cash in the form of other instruments in the form of cards or securities (debit cards, credit cards, electronic money, checks, bilyet and other cards / securities issued by banks), in particular in the form of nonmonetary payments, use the intermediaries of ATM (ATM), CDM (ATM), EDC (electronic data capture), Tap Reader (for electronic money), as well as Internet banking or SMS Banking networks that can be used via mobile media, tablets, Laptop or computer should be one of its own attractions for consumers in terms of comfort and security of transactions.In addition, a survey was conducted by the Katadata Insight Center (KIC) among 20,000 respondents in 34 provinces during the online shopping festival from August 27 to September 9, 2018. The result was that $76.08 \%$ of respondents having carried out transactions in electronic commerce have made a non-payment in cash. On this basis, it can be concluded that the trend in nonmonetary transactions is increasingly demanded by the public, so it is interesting to examine whether non-monetary transactions have an influence on the financial performance of a business. This research focuses on public banks (BUMN), namely PT. Bank Rakyat Indonesia (Persero) Tbk, with the reason that in addition to being the oldest commercial bank, currently PT. Bank Rakyat Indonesia (Persero) Tbk is also the largest bank that has an ATM in Indonesia, until September 2019, PT. Bank Rakyat Indonesia has 20,846 ATM. 
In addition, this study divides non-monetary transactions into separate variables, namely debit / ATM cards, credit cards, checks and Bilyet transfers, electronic money and mobile banking (MB). Indeed, this study wants to combine all the variables of non-monetary transactions in the study of Kamboh \& Leghari [1], Itah \& Emmanuel[2], concerning the use of the atmosphere, Pramono et al[3], Sitorus,[4] and Hafidh \& Sholeh[5], on credit cards, while electronic money and mobile banking refer to the research of [6], [7] and [8]. This study also added the variables of non-monetary transactions Check and Bilyet Giro as a differentiator from previous research, as well as Check and Giro at PT. Bank Rakyat Indonesia (Persero) is a cashless transaction item with a basic income different from other cashless transactions, in accordance with the Fee Based Income cashless distribution table at PT. Bank Rakyat Indonesia (Persero):

Table 1. Fee Based Income Cashless Banking PT BRI

\begin{tabular}{cc}
\hline Variable & Fee Based Income \\
\hline & ATMServices \\
Debit/ATM Card & PINSubstitution \\
& Card change \\
Kredit Card & Cooperation income from using ATMs \\
& Annual Fee \\
Checksand Giro & Transaction fee \\
E-Money & Issuance Fee \\
& Transaction fee \\
Mobile Banking & Card Issuance Fee \\
& Bill Fee \\
& Payment Fee \\
\end{tabular}

Can be seen in table 1.1 at PT. Bank Rakyat Indonesia (Persero) has a variety of cashless transactions, and each cashless transaction has a different source of income which can be seen in the table. Besides aiming to find out whether cashless transactions have an influence on financial performance, this study also wants to find out whether there are differences in financial performance consisting of profitability and liquidity ratios before and after the NonCash National Movement (GNNT), this is based on the phenomenon of Bank Indonesia as a the central bank together with the government announced the Non-Cash National Movement (GNNT) on August 14, 2014. Based on the Non-Cash National Movement (GNNT) program it is interesting to know whether there are differences in financial performance consisting of profitability ratios (ROE) and liquidity (LDR) before and after the GNTT program. The financial performance in this study is only focused on the profitability ratio (ROE) and liquidity (LDR), this is because ROA and LDR are the financial performance of companies that refer to Bank Indonesia Regulation Number 13/1 / PBI / 2011 regarding bank health assessments, and it is also a ratio that reflects financial performance which is widely used research on the performance of banking companies

\section{Literature Review}

\subsection{Cashless Banking}


Non-Cash Transactions are transactions that use instruments without involving cash. Current payment instruments can be classified in cash and non-cash.

\subsection{Banking Financial Performance}

In this study the ratio used in the aspect of profitability is ROE (Return on Equity). ROE compares net income after tax with the equity that has been invested by the company's shareholders. As for the liquidity ratio, the ratio used is the LDR (Loan to Deposit Rastio). LDR ratio is the ratio of loans given to third parties (current accounts, savings, time deposits and certificates of deposit). This LDR is intended to measure the ability of banks to meet repayment of deposits that are past due to their customers and can fulfill loan applications submitted without delay[9].

\subsection{Research Model and Hypothesis}

The test in this study will be divided into two testing schemes, the first will be testing how the influence of cashless banking variables on bank financial performance, the second test will be seen whether there are differences in the financial performance of banks before and after the declaration of the National Non-Cash Movement by Banks Indonesia.Research conducted by Karimzadeh, Emadzadeh, \& Shateri[10],on succeeding in finding Electronic banking significantly positive effect on bank profitability while other research, by [2]proved that ATM usages had a significant effect on ROE.Research conducted by [5]with the aim of analyzing non-cash transactions (less-cash transactions) in influencing money demand succeeded in finding that the transaction variable proxy for non-cash transactions namely the number of credit card holders (KK), has a positive value and significant, to bank profitability. Research Pramono et al[3]with the title Impact of Non-Cash Payments on the Economy and Monetary Policy (Working Paper) managed to find that the development of non-cash payment instruments is positively related to velocity of money. Then Berger \& DeYoung[11], In a study in the United States, with a sample of 424 banks using internet banking and 5,175 noninternet banking banks (1999-2001) found that the adoption of Internet Banking at banks succeeded in increasing bank profitability, specifically through the value of increase in income from savings administration costs.

H1-H5: Debit / ATM Cards, Credit Cards, Checks and giro, e-Money and Mobile Banking Transactions have a positive effect on profitability

GNNT is a government program to educate and disseminate information to the public through the practice of using non-cash instruments. This can be utilized by banks to introduce their products and services, which in turn will improve the performance of the banks themselves, both in terms of liquidity and profitability, thus the existence of the GNNT program is information that can improve financial performance. This is supported by research by Nalwaya \& Vyas[12] and Akhtar \& Iqbal[13]which prove that financial profits have increased after the acquisition.

H6,H7: There are differences in profitability and liquidity before and after the National NonCash Movement 


\section{Research Method}

This research is an empirical study of conventional banks in Indonesia (Case Study at PT. Bank Rakyat Indonesia, Tbk) and will be divided into two types of testing methods. The first test method will explain the causal relationship between independent variables to the dependent variable through hypothesis testing. While the second testing method uses the case study method. In this second test, the event examined was defined as the year the Non-Cash National Movement (GNNT) began by Bank Indonesia, which was August 2014. The first test method will explain the causal relationship between independent variables to the dependent variable through hypothesis testing. While the second testing method uses the case study method. In this second test, the event examined was defined as the year the Non-Cash National Movement (GNNT) began by Bank Indonesia, which was August 2014. The data used in this first test are time series data per quarter from 2012 to 2018 . While for the second test (comparative test), the data used are data on quarterly financial performance collected 10 quarters before August 2014 and 10 quarters after August 2014. This research will use two methods of testing / analyzing data, namely: (1) Multiple Linear Regression Analysis Method, and (2) Case study method using Analysis of Different Tests (Paired Sample t-Test).

\section{Results and Analysis}

\subsection{Result}

The results of this research from the five independent variables which are types of noncash (cashless) transactions namely Debit / ATM Card, Credit Card, Check and Giro, eMoney, and Mobile Banking which have the biggest influence on the dependent variable profitability at PT. Bank Rakyat Indonesia, Tbk is an e-Money transaction because it has the largest beta value compared to other independent variables.

The calculation results show that the significance value of the paired-samples $\mathrm{T}$ Test output calculation is smaller than 0.05 , which means there are differences between financial performance variables measured using Return on equity before the Return on equity after the movement to use non-cash payment instruments launched by Bank Indonesia on August 14, 2014. While the significance value of the calculated paired-samples $T$ Test output for the liquidity variable is greater than 0.05 , which means there is no difference between the liquidity ratio variables before the Non-Cash National Movement and the liquidity ratio after the NonCash National Movement (GNTT), in other words the initial hypothesis which states there are differences in liquidity before and after the Non-Cash National Movement, is not supported.

\subsection{Analysis}

Based on the calculation results it can be seen that the non-cash transaction variable measured using a Debit Card / ATM transaction positively influences the return on equity ratio. So the hypothesis stating "Card-Based Instrument Transactions (Debit Cards / ATMs) has a positive effect on Banking Profitability", supported. The influential results are in line with research by Karimzadeh et al[10] and Itah \& Emmanuel[2]which prove that ATM usages significantly influence ROE.In addition, the results of this study prove variable measured using credit card transactions has a positive effect on the ratio of return on equity. So the 
hypothesis stating "Credit Card Card Based Instrument Transactions have a positive effect on Banking Profitability", is supported. Influential results have in common with research by Sitorus[4] and Hafidh \& Sholeh[5]which proves that non-cash transactions, namely the number of credit card holders, have a positive and significant value on bank profitability.

Based on the calculation results, it can be seen that the variable paperbased transaction instrument Checks and Bilyet transaction has no effect on the ratio of return on equity. So the hypothesis stating "Paper Based Instrument Transactions (Checks and Bilyet) has a positive effect on Banking Profitability", is not supported. In addition, the results of this study provevariable measured using Mobile Banking transactions positively influences the ratio of return on equity. So the hypothesis stating "Mobile Banking Transactions has a positive effect on Banking Profitability", is supported. The influential results are in line with the research of Sukkar \& Hasan[14]and Berger \& DeYoung[11]which proves that the adoption of Internet Banking at banks has succeeded in increasing bank profitability, specifically through the value of increasing income from savings administration costs.

The results of this study also prove that there are differences between the ROE variables before the existence of GNNT and ROE after the existence of GNNT in other words, the hypothesis which states that there are differences in bank profitability before and after the NonCash National Movement is supported. The results of this study are similar to Nalwaya \& Vyas[12], Akhtar \& Iqbal[13]andBerger \& DeYoung[11] where banks that use internet banking have a greater percentage of ROA and ROE compared to banks that do not use. Return on equity is a ratio to measure the ability of banks to obtain profits and overall operational efficiency through the use of own capital.In addition, the results of this study provethat there is no difference between the LDR variables before the existence of GNNT and the LDR after the existence of GNNT in other words, the hypothesis which states "There are differences in banking liquidity before and after the Non-Cash National Movement, is not supported. These results are similar to the study of Sarah[15] which proves that FDR that reflects liquidity is not significantly different between before and after Branchless Banking. But contrary to the results of Elfaliyanti \& Nurdin[16] research which proved the financial performance in the form of liquidity showed a significant difference after there was a signal that showed good information [16].

The results of the study prove that the value of e-money transactions has the greatest influence on PT. Bank Rakyat Indonesia, Tbk. The results of this study can also be a recommendation that PT. Bank Rakyat Indonesia, Tbk can maintain and increase the use of emoney by encouraging customers to give testimonials from consumers who have used it and can provide tangible forms of accountability for problems faced by consumers when using emoney.Due to limited data access, this study only uses data on non-cash transaction volume (cashless), not the frequency of non-cash transactions. Future studies are also expected to be able to use frequency data for using non-cash transaction items that can systematically increase company profits.

\section{Conclusion}

Based on the calculation results it can be seen that the non-cash transaction variables measured using Debit / ATM Card transactions, Credit Card transactions, e-Money transactions and Mobile Banking transactions positively affect the return on equity ratio. Whereas the paper based instrument of the check and bilyet transaction instrument does not 
affect the ratio of return on equity. And it can be concluded that of the five independent variables which are types of non-cash transactions namely Debit / ATM Card, Credit Card, check and bilyet transaction, e-Money, and Mobile Banking which have the biggest influence on the profitability dependent variable, is an e-Money transaction because it has the largest beta value in the coeficient standard table. The results of the study prove that there are differences between the ROE variables before the existence of GNNT and the ROE after the presence of GNNT. In addition, the results of the study prove that there is no difference between the LDR variables before the existence of GNNT and the LDR after the existence of GNNT, in other words the hypothesis which states that there are differences in liquidity before and after the Non-Cash National Movement, is not supported.

\section{References}

[1] K. M. Kamboh dan M. E. J. Leghari, "Impact of cashless banking on profitability: A Case study of banking industry of Pakistan," Paradigms, vol. 10, no. 2, hal. 82, 2016.

[2] A. J. Itah dan E. E. Emmanuel, "Impact Of Cashless Banking on Banks' Profitability (Evidence from Nigeria)," Asian J. Financ. Account., vol. 6, no. 2, hal. 362-376, 2014.

[3] B. Pramono, T. Yanuarti, P. D. Purusitawati, dan Y. T. Emmy, "Dampak Pembayaran Non Tunai Terhadap Perekonomian dan Kebijakan Moneter,” Pap. Bank Indones., 2006.

[4] S. R. Sitorus, "Analisis Pengaruh Penggunaan Kartu Pembayaran Elektronik dan Daya Substitusi Transaksi Non Tunai Elektronik Terhadap Transaksi Tunai Indonesia," Fak. Ekon. dan Manaj. Inst. Pertan. Bogor, 2006.

[5] A. A. Hafidh dan M. Sholeh, "Analisis Transaksi Non-Tunai (Less-cash Transaction) dalam Mempengaruhi Permintaan Uang (Money Demand) Guna Mewujudkan Perekonomian Indonesia Yang Efisien," in Prosiding Seminar Nasional, 2016, hal. 750-764.

[6] I. Hernando dan M. J. Nieto, "Is the Internet delivery channel changing banks' performance? The case of Spanish banks," J. Bank. Financ., vol. 31, no. 4, hal. 1083-1099, 2007.

[7] W. Poon, "Users' Adoption of e-Banking Services: the Malaysian Perspective," J. Bus. Ind. Mark., 2008.

[8] N. N. S. Novita, Linda dan I. G. A. K. Giantari, "Peran Sikap Dalam Memediasi Pengaruh Perceived Usefulness Terhadap Niat Menggunakan Internet Banking Di Kota Denpasar," E-jurnal Manaj. Unud, vol. 5 No.3, no. 2302-8912, hal. 1513-1541, 2016.

[9] I. Fahmi, Pengantar Manajemen Keuangan. Bandung: Alfabeta, 2018.

[10] D. S. D. Karimzadeh, D. M. Emadzadeh, dan J. Shateri, "The effects of electronic banking expansion on profitability of a commercial bank (Sepah bank of Iran)," Indian J. Sci. Res., vol. 4, no. 6, hal. 305-312, 2014.

[11] A. N. Berger dan R. DeYoung, "Technological Progress and The Geographic Expansion of the Banking Industry," J. Money, Credit Bank., hal. 1483-1513, 2006.

[12] N. Nalwaya dan R. Vyas, "Pre-Post Merger Financial Performance: An Analysis of ICICI Bank with Bank of Rajasthan Ltd.," Pacific Bus. Rev. Int., vol. 5, no. 6, 2012.

[13] S. Akhtar dan J. Iqbal, "An empirical analysis of pre and post merger or acquisition impact on financial performance: a case study of Pakistan telecommunication limited," Eur. J. Account. Audit. Financ. Res., vol. 3, no. 1, hal. 69-80, 2014.

[14] A. Al Sukkar dan H. Hasan, "Toward a model for the acceptance of internet banking in developing countries," Inf. Technol. Dev., vol. 11, no. 4, hal. 381-398, 2005.

[15] H. Sarah, "Dampak branchless banking terhadap kinerja keuangan PT bank muamalat indonesia Tbk," Al-Muzara'ah, vol. 3, no. 2, hal. 136-157, 2015.

[16] D. Elfaliyanti dan N. Nurdin, "Analisis Perbandingan Kinerja Keuangan Perbankan Sebelum dan Setelah Terkoneksi Gerbang Pembayaran Nasional (GPN),” 2019. 